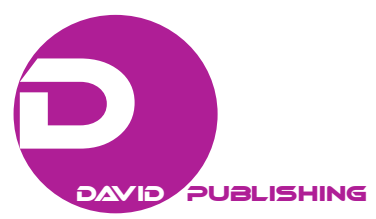

\title{
Anselm and Heidegger: A Disquieting Analogy
}

\author{
Maria Leonor Xavier \\ University of Lisbon, Lisbon, Portugal
}

\begin{abstract}
This article deals with the human design of salvation and the question of man under the common stimulus of two grand names of philosophical tradition, though parted by more than nine centuries: Saint Anselm and Martin Heidegger. Both defend the need for a God who saves man: according to Anselm, due to the consequences of evil, which man consented and cannot revert; according to Heidegger, due to the consequences of technicity, which man created and can no longer control. In any case, the design of salvation posits the question of man: Why man? This question was considered ever since the remote 12th century, in a time of renovation for European culture, and is once again posited with special acuteness in our days, in a time of accelerated technological progress of human civilization. Which is why Anselm's reflection around salvation and the medieval question of man may open doors towards re-equating the value of man in its actual state and in the future horizon of humanity?
\end{abstract}

Keywords: Saint Anselm, Cur Deus Homo, man, salvation, Martin Heidegger, philosophy of religion, philosophy of technicity

\section{The Design of Salvation ${ }^{1}$}

In an interview conceded to the German magazine Der Spiegel, in 1966, Martin Heidegger brought to word the famous sentence: "Only a God can save us now". The philosopher referred to human condition in the age of technicity, that is, the human being in face of "the mystery of the planetary domination of the unthought essence of modern technicity" (1976, p. 125). Indeed, the development of modern technicity shows that this is no mere instrument at the service of man. Even if one considers that technicity is a creation of man, the creature of man has grown in such a way that it supplanted its creator and is no longer entirely under man's domain. Before the greatness of the world of technicity, the consequences of which supersede human control, man stands threatened, diminished, and impotent. Insofar as the human being can no longer help himself in face of that which overpowers him, “only a God can save us now”. More than 50 years after Heidegger’s interview, the premonitory nature of his statement is not difficult to acknowledge.

Heidegger's sentence also reveals that, when man is in question, God arises as last resort and limit-appeal even in an era when God is supposedly dead. Let us not forget, however, that it was man who was in question in the death of God. Nietzsche's philosophy is a visceral reaction against Judaic-Christian tradition because the latter had domesticated man; it had humiliated him and deprived him of his original vigor. When God dies or resurrects, it is always man who is in question. It seems that God's life and death have gone with the flow of mutations in the question of man. Saint Anselm's theological thought is extremely cautious and wary of any

Maria Leonor Xavier, Associate Professor, Director of the Department of Philosophy, University of Lisbon, Lisbon, Portugal.

1 This part of the article was presented at the XVI Latin-American Congress of Medieval Philosophy, organized by the Centro de Estudios Medievales da Universidad Gabriela Mistral and the Red Latinoamericana de Filosofía Medieval, which took place in Santiago do Chile, 24th to 26th of May 2017. 
instrumentalization of God by man. Anselm's God does not serve the interests of man. If he did, he would be a lesser God, and not "something than which nothing greater can be thought" ${ }^{2}$. Hence, Anselm's God would not come to the rescue of man on account of his interests, nor would he take amorous pity on man, were men not in his designs. Hence, Anselm did not say that God rescued man for love. That which Anselm says, however, may be translated by something similar to what Heidegger said: Only a God was able to save man.

But save man from what? Anselm could not be thinking of the uncontrollable consequences of modern technicity. Let us start from the beginning. According to biblical cosmogony, the primitive human couple ate the forbidden fruit and hence came to know good and evil. Such is the knowledge that characterizes human condition. But the knowledge of good and evil is the knowledge of uncontrollable consequences for man. Before such consequences, man is rendered impotent and in need of salvation, what only a God may provide. Indeed, it is part of human condition to know not only the evil of suffering pain, loss, and death, but also the evil of acting against virtue, duty, and life. The book of Job teaches us that the evil of suffering is not to be explained by the evil of acting and therefore escapes the domain of the suffering man. Notwithstanding, Saint Augustine, zealous in his thought, took the transgression of the primitive couple as an evil of acting, from whence he derived all the evil of suffering of human nature. The vulnerability of human condition, in view of which man cannot help himself and requires divine intervention, is thus due to an original transgression understood as a moral $\sin ^{3}$. It is in the tradition of Augustine's thought that medieval theologians, among whom the author of the Cur Deus Homo, try to make sense of the sin which renders man a being in search for salvation.

Anselm had reflected on the sense of sin in the opuscules De libertate arbitrii and De casu diaboli. In the first one, man is a being of freedom whose mission is to unconditionally guard justice, which is the rectitude of will. But, without any sort of coercion, sponte, he failed in his mission, thus forfeiting the justice whose guard was in his nature. The sin of man is an internal forfeiture of justice ${ }^{4}$. In the second opuscule, which deals with the fall of the angel, a being more perfect than man and hence less vulnerable than him, Anselm furthers the sense of this forfeiture as a lack of perseverance. ${ }^{5}$ In its essence, moral sin is a spontaneous lack of perseverance in justice. In Cur Deus Homo, that internal forfeiture of justice is the contraction of a debt which man cannot repay. Only a God can save man, thereby helping him to repay his debt. But to whom is man indebted? To God himself. And if so, must God really claim man's debt? Can he not forfeit such a debt? No. Such is Anselm's negative answer, which is usually summed up in the doctrine of the satisfaction of divine honor and caused great scandal among 20th century theologians ${ }^{6}$. However, Anselm's answer deserves to be understood before being reduced to a desultory and cursed doctrine.

\footnotetext{
2 “Et quidem credimus te esse aliquid quo nihil maius cogitari possit”. Proslogion 2, ed. Schmitt: I, 101, in Corbin (Dir.), 1, 1986, p. 244.

3 See De Civitate Dei XIV, 11-15, in Biblioteca de Autores Cristianos (Dir.): 172, pp. 95-110.

4 “[...] deserere voluntatis rectitudinem est peccare”. De libertate arbitrii 3, ed. Schmitt: I, 212, in Corbin (Dir.), 2, 1986 , p. 218.

5 See De casu diaboli 2-3, ed. Schmitt: I, 235-240, in Corbin (Dir.), 2, 1986, pp. 286-296.

6 According to the doctrine of satisfaction, the sacrifice of God-man at the cross occurred to satisfy the honor of God, which had been offended by man's incurrence in sin. This doctrine perniciously discentred God's love for man as a determining cause of the divine initiative of salvation, and hence became a commonplace criticism against Anselm's soteriology. Despite acknowledged by great 20th century theologians, such as Hans Urs von Balthasar, 1962, who dedicates Anselm a chapter in his magnum opus Gloria II (1962), thereby frequently evoking the Cur Deus Homo, Saint Anselm's theological legacy, his work Cur Deus Homo, predominantly fell out of favor after Victor Aulen's, 1970, and Louis Bouyer's criticism, 1974. Michel Corbin, director of the French modern edition of Saint Anselm's works, undertakes a retrospective of the controversy in his long introduction to the text Cur Deus Homo: see Corbin (Dir.), 1988, pp. 17-25.
} 
The human being contracted a moral debt which he cannot repay, and which God must claim. On the one hand, man cannot repay his debt due to the greatness of He to whom he is indebted, that is, due to divine greatness. $^{7}$ As such, we should reflect in what consists divine greatness according to Saint Anselm, who is, per excellence, the thinker of divine greatness. According to his famous unique argument—“something than which nothing greater may be thought”, God is something insurmountably thinkable and hence something thinkable with a greatness more than supreme, for insurmountable. Now, given its indetermination, the concept of an insurmountably great thinkable could seem an empty concept, were it not for the aid of Anselm himself, who helps us think such a concept in his reply to Gaunilo's critique of his unique argument. Anselm holds as reference points, that is, as terms of comparison with divine greatness, two thinkable totalities, world and time: Just as the world is present in all its parts and time in all its moments, so is God omnipresent; but unlike the world, which is not entirely present in each of its parts, and time, which is not entirely present in each of its moments, God is totally present in any part and any time. If God were not to distinguish himself thus from world and time, his attribute of greatness, which is his omnipresence, would not be compatible with the attribute of his perfection, which is his simplicity. World and time are thought as omnipresent greatnesses, but not as entirely omnipresent in each of their respective parts, and hence they are surmountable by something that cannot but be indivisibly omnipresent. Anselm's concept of God, that is, the concept of something insurmountably thinkable, is therefore a totally omnipresent greatness or plenitude: God is entirely in everything ${ }^{8}$. Hence, we can say that Anselm's thought on divine greatness is pantitheistic. As such, and given that the human being contracted a moral debt before God, by forfeiting the justice that his freedom was entrusted to guard, where can man search for the justice that he forfeited and which he must repay God? How could the human being exteriorize himself from God's total omnipresence? And where could the human being search for the justice he forfeited outside of God? In truth, only God has unwavering justice, for his freedom is to guard it with indeclinable firmness. Hence, which debt of justice could man repay God that has not already been claimed by God himself? Only God can restore to himself that which man owes.

As such, then, only God can repay man's debt. And yet, must God repay such a debt? Would it not be more consentaneous with his kindness to be magnanimous and forgive mankind's moral debt? Saint Anselm is also a thinker of divine goodness: It is as summum bonum, that is, as supreme and insurmountable good, that God arises in thought in the first path of the Monologion ${ }^{9}$; and it is as illimitable and immutable good, as something insurmountably thinkable, that God is to be thought in the unique path of the Proslogion ${ }^{10}$. However, the divine attributes of goodness and justice cannot conflict between themselves. God cannot forfeit or not persevere in his essential justice ${ }^{11}$, and the latter demands for the reparation of the human fault. If God forgave without reparation, his goodness, which includes his mercy, would be without justice. Since a just goodness is better than an unjust goodness, the good God cannot but be just. Between heart and reason, reason supersedes the heart and hence the will of God is never irrational ${ }^{12}$. It is this primacy of reason and justice over the heart and love that sustains the doctrine of satisfaction in Anselm's theology of the Cur Deus

\footnotetext{
7 See Cur Deus homo I, 19-25, ed. Schmitt: II, 84-96, in Corbin (Dir.), 1988, pp. 374-398. Henceforth CDH.

8 See Quid ad haec respondeat editor ipsius libelli [1], ed. Schmitt: I, 131-132, in Corbin (Dir.), 1, 1986, pp. $300-302$.

9 See Monologion 1, ed. Schmitt: I, 14-15, in Corbin (Dir.), 1, 1986, pp. 58-60.

10 See Quid ad haec respondeat editor ipsius libelli [8], ed. Schmitt: I, 137, in Corbin (Dir.), 1, 1986, p. 312.

11 Divine justice is distinguished by being inseparable from God, unlike human justice, which man can forfeit: see De veritate 12 , ed. Schmitt: I, 196, in Corbin (Dir.), 2, 1986, p. 170.

12 “Voluntas namque dei numquam est irrationabilis”. CDH I, 8, ed. Schmitt: II, 59, 11 in Corbin (Dir.), 1988, p. 324.
} 
$H_{0 m o}{ }^{13}$. However, neither does such a doctrine exhaust the meaning of the work, nor does the divine attribute of justice confine with a mere and basic vengeful sense of justice ${ }^{14}$.

Only a God could repair the human fault and save man, but why through the sacrifice of a God-man who dies at the cross? Could God not have rescued man some other way? The passion and death of a God-man at the cross, do they not refute the divine attribute of omnipotence? On the one hand, Anselm takes it upon himself to underline that Christ's obedience means not weakness but an attitude of full conformity with divine justice. ${ }^{15}$ But, on the other hand, could not have God relinquished the chalice of such sacrifice, thus rescuing humanity through the sacrifice of a man or an angel? Anselm's answer arises precociously in the order of composition of the Cur Deus Homo: no, because such a modality would submit humanity to a man or an angel and thus offend human dignity ${ }^{16}$. Man should not submit but to God, that is, to a truly greater reality, not to an equal or to a lesser god. The connection to God is man's freedom as opposed to the slavery of man by man or by some lesser God. Thus, for Augustine, it is also the amor Dei which commands the City of God and prevents man from becoming a servant of man, as is the case in the earthly city, which is dominated by man's egocentric love ${ }^{17}$. Only a God-man could save man, thus safeguarding his dignity: This is one of the most relevant theses of Anselm's theology in the Cur Deus Homo.

\section{Why Man?}

But why save humanity? This question cannot be answered but through the answer to a more fundamental one: cur homo? Why man? This question was widely debated in 12th century Europe, especially in the school of Laon, as is shown in M.-D. Chenu's classical study La Théologie au Douzième Siècle (1976, pp. 52-61). This question has an exegetic nature and dates back to Gregorius Magnus' interpretation of the parable of the ten drachmas (Luc. 15, 8), who connoted the nine drachmas with the nine orders of angels, and the 10th drachma, lost and re-found, with man. Still in the course of the 11th century, amid his reflections on the Cur Deus Homo, Anselm too is inevitably confronted with the question: Why man? Anselm's answer is that humanity's greatest purpose is the perfection of the celestial city, that is, the perfect conclusion of the divine work of creation ${ }^{18}$. By the 12th century, the question was divided between two positions: Was man a nature worth creating in view of his own dignity, or was he an accident in the history of creation? It is no coincidence that this question, which M.-D. Chenu reports as a pungent question at the time, has been debated in a Europe experiencing a spell of considerable material and spiritual development, marked by the growth of cities and the

\footnotetext{
${ }^{13}$ See CDH I, 12-13, ed. Schmitt: II, 69-71, in Corbin (Dir.), 1988, pp. 344-348. "Si Deo nil maius aut melius, nihil iustius quam quae honorem illius seruet in rerum dispositione summa iustitia quae non est aliud quam ipse deus”. CDH I, 13, ed. Schmitt: II, 71, in Corbin (Dir.), 1988, p. 348.

${ }^{14}$ We consider the greatest reach of divine justice on the level of the scatological plane of Creation, in "Christologie et Théodicée dans le Cur Deus Homo de saint Anselme”, in Gilbert, alii, 1999, pp. 503-514.

${ }^{15}$ See CDH I, 8-10, ed. Schmitt: II, 59-67, in Corbin (Dir.), 1988, pp. 324-340. “A. Non ergo coegit deus Christum mori, in quo nullum fuit peccatum; sed ipse sponte sustinuit mortem, non per oboedientiam deserendi vitam, sed propter oboedientiam servandi iustitiam, in qua tam fortiter perseveravit, ut inde mortem incurreret”. CDH I, 9, ed. Schmitt: II, 62, in Corbin (Dir.), 1988, p. 330. 16 "A. An non intellegis quia, quaecumque alia persona hominem a morte aeterna redimeret, eius servus idem homo recte iudicaretur? Quod si esset, nullatenus restauratus esset in illam dignitatem, quam habiturus erat, si non pecasset: cum ipse, qui non nisi dei servus et aequalis angelis bonis per omnia futurus erat, servus esset eius, qui deus non esset et cuius angeli servi non essent”. CDH I, 5, ed. Schmitt: II, 52, in Corbin (Dir.), 1988, p. 310.

17 See Saint Augustine, De Civitate Dei XIV, 28, in Biblioteca de Autores Cristianos (Dir.), 1978, pp. 137-138.

18 "B. Intelligo iam necesse esse, ut deus faciat quod incepit, ne aliter quam deceat videatur a suo incepto deficere.- - Sed si ita est, videtur quasi cogi deus necessitate vitandi indecentiam, ut salutem procuret humanam”. CDH II, 4-5, ed. Schmitt, II, 99, in Corbin (Dir.), 1988, p. 404; "Dicamus tamen quia necesse est, ut bonitas dei propter immutabilitatem suam perficiat de homine quod incepit, quamvis totum sit gratia bonum quod facit”. CDH II, 5, ed. Schmitt, II, 100, in Corbin (Dir.), 1988, p. 406.
} 
renovation of religious life, as is indicated by the Cistercian reformation and the surge of new religious orders. This was a fulgurous era, an era of hope for the medieval man. And it was in such an era that the question of man: “cur homo?” came to be.

This medieval question must bring to mind a primeval antecedent of the question of the value of man, which now resurfaces with perhaps unsuspected pungency and radicality. Indeed, we live an era of civilizational vigor, characterized by a fast-paced progress of technological knowledge which causes awe and fear in contemporary men. Awe and fear perhaps are the ingredients of the question which so distinctly returns: Why man?

In the scale of geological time, we now live in the Age of Man, the Anthropocene, and never before was man so explicitly in question. Since this is a very recent concept of origin, the debate naturally still revolves around the birth date of the Anthropocene: whether it coincides with the most recent age of the history of the Earth, the Holocene, or whether it starts with the advent of agriculture, and hence the Neolithic, or whether it commences with the modern era of the history of humankind, namely, the age of industrialization, from the 18th century onwards. What is incontrovertible, however, is the impact that human civilization now exerts on Earth's life. The decisive demographic increase of human population, as a consequence of better living conditions, has rendered man the king of Earth. Now, this reign brought along harmful consequences which require ponderation. Indeed, man's intensive and intrusive occupation of Earth has drastically diminished the number of wild species, that is, biodiversity, while massively reproducing animal species submitted to man's food chain since the dawn of agriculture, now devoid of all autonomy and survival skills in wildlife. Furthermore, the industrial era, along with man's demographic pressure, has produced chain consequences in the biosphere, such as pollution, the greenhouse effect, global warming, and climate change, which now alter the configuration of the earth's crust.

In view of the dire consequences of human's reign over the Earth, one may consider three doors through which to escape: either trust in Nature; or betting in Politics; or the imperative of Ethics.

On the one hand, it is possible to salvage a sovereign concept of Nature which, instead of capitulating before the intrusion of human civilization, renders this into a metamorphosis of its life and even a detail in its history. By doing so, we are of course thinking in the scope of a cosmological concept of Nature which supersedes the classic concept of sensible nature, and hence embraces not only the life and death of plants, but the life and death of stars. At this scale, the history of humanity and its impertinencies is incontrovertibly submitted to the life and death of the star that sustains Earth, the Sun. The death of the Sun will one day absorb all that is on the face of the Earth and Earth itself. As such, then, the door of Nature is in itself a catastrophic way out for the destiny of humankind.

Surely one such door will not be opened during our lifespan, not even during that of more or less distant generations. Still, it is possible to act from within human civilization in order to render Earth inhabitable, and well inhabitable, for future generations. Such is the bet in politics, to attempt to bridle and reverse the evils of human civilization on Earth, as well as the diminishment of biodiversity and climate changes. But is it to be expected that the political powers of Earth unite in an efficient accord concerting public policies to save the Earth, and with it the sustainability of human life, when some of those powers accumulate military weaponry capable of altering the inclination of the Earth's rotating axis? As necessary and urgent as it may be, we cannot surmise a timely opening of such a door. The love of humanity and Earth is not the highest value in politics, which is why this is not a solution capable of preventing the catastrophe predicted by science. 
And is the love of humanity an uppermost value of ethics nowadays? Ethics was once thought as the abode of man, wherein the latter is capable of attaining the best that he can be, be it in his relation to himself, through virtues such as temperance, or in his relation to others, through virtues such as justice. Presently the impact of human civilization upon life on Earth has discentered man in ethics, giving rise to concepts such as environmental ethics and animal ethics. These concepts of an applied ethics render evident that ethical responsibility regards not only the relation of each individual with himself and the relation between humans, but also one's relation with the environment and other animals. This broadening of ethics is necessary to the self-regulation of the power of man over Earth.

However, instead of searching for balances in man's reach, as was once taught by Aristotle, the ethical thought of our days explores paths which turn ethics against man and render it anti-humanist. Such are the paths that dissolve the distinction and ordination of animal species, which condense specism as immoral and advocate vegetarianism as a moral option. What impact would the vegetarian conversion of man have upon life on Earth? Men would perhaps become less aggressive and that would soothe the problems of relations between humans, but would that solve such problems? Meek or domesticated animals in the food chain, would they survive as man's pets? And how were we to regulate the relation of humans with wild animals: Would the latter be circumscribed to reserves or would they vanquish humans, which by then would have lost aggressiveness? And even if they were not to eat other animals, would human beings be able to inhabit the Earth without killing other animals? Can someone avoid inadvertently stepping on a trail of toilsome ants or some harmless snail, or other less than sympathetic bugs in popular imagination? Only if man were light and spiritual as an angel. Were we angels, we would not step on ants. But angelic perfection was an ideal for medieval monks, not for today's men. Or does the value of animal equality rekindle in us the desire to be angels? In reality an animal ethics which intends to indiscriminately respect the interests and preferences of all animals is incompatible with the very animality of the human being.

Man created technicity and this allowed for the mechanization of production and freed man from much heavy work; the knowledge of technicity developed and constituted technology, including the technology of information, which enabled the informatization of services in modern societies and freed man from much administrative work. The progress of technicity and technology freed man from work to leisure, but that also means it generated unemployment, since remunerated work is still a source of sustenance for most human beings who lead an autonomous life. One needs to find an alternative to remunerated work for the sustenance of human beings, something that is yet to be discovered. Perhaps economy will attend the need to create such an alternative.

And if so, how will the great multitude of human beings occupy their time? With science, with art and thought? Science for science's sake? Art for art's sake? Thought for thought's sake-for being and thinking is one and the same, as was taught by Parmenides? When we have time, will we want to go back to the old ideals of our decrepit humanity? This is highly doubtful, for by then, will we still want to be human?

Some already wish to be more than human, that is, trans-human, thereby supplanting the limitations, weaknesses, and nuisances which characterize human condition. The progress of technology enlivens the trans-humanist thought, that is, the defense of a perfectibility of the species while putting a halt to aging and improving the intellectual capacities of the human being. Technology, once applied to the perfectibility of the species, can be not only biotechnology, producing genetic alterations to the species, but also robotics, producing artificial intelligences in mechanical supports. This double path towards creating trans-human beings 
excites and exalts many individuals, especially those more involved in technological knowledge, while it frightens and petrifies many others, which therein sense the end of man. Heidegger was right: Technicity, the creature of man, is no longer in man's hands.

The technology capable of creating trans-human beings, more perfect than humans, heralds the death of man. Trans-human beings will also produce science, art, and thought, in a fashion much more qualified than human beings. Is there anything in human beings worth preserving, or just misery, infirmities and frailties?

Regard this is a reflection by Saint Augustine on the contribution of diversity towards the perfection of the world. If there is a Sun, why should there be a Moon? And if there is a Moon, why should there be lamps which guide us through the night? Just as it is ridiculous to think that lamps should not exist on account of the Moon, it is also petty to think that there should not be a Moon on account of the Sun. This is the same as thinking that instead of a Moon and a Sun, there should be two Suns; and, quite analogously, that instead of men and angels there should be but angels, as well as instead of human being and trans-human beings, there should be but trans-human beings. But to exclude the Moon and replace it with another Sun, just as excluding men in favor of angels or trans-human beings, this is the same as simultaneously subtracting a perfection from the universe so as to add another one. Now, to think of excluding a lesser perfection from the universe so as to add a greater one is a perfectionist thought, yet one devoid of generosity and goodness ${ }^{19}$, and hence it is ethically condemnable. But the same ethical reproach is to be applied to the sacrifice of biodiversity at the hands of human civilization Man's discentered ethics allows not for the salvation of man.

Anselm believed in a God who would not conclude the universal work without human beings, but in the celestial city. Today's man is still profoundly vulnerable to a design of salvation, but in the terrestrial world. Maybe Heidegger is indeed right: "Only a God can save us now”.

\section{References}

Aulen, V. (1970). Le Triomphe du Christ. Paris: Aubier.

Balthasar, H. U. V. (1962). Herrlichkeit. Fächer der Stile: Klerikale Stile. Einsiedeln: Johannes Verlag.

Biblioteca de Autores Cristianos (Dir.). (1978). Obras de San Agustín. XVII. Madrid: La Editorial Catolica.

Bouyer, L. (1974). Le Fils éternel. Paris: Cerf.

Chenu, M.-D. (1976). La Théologie au Douzième Siècle. Paris: Vrin.

Corbin, M. (Dir.). (1986a). L'Oeuvre d'Anselme de Cantorbéry 1. Paris: Cerf.

Corbin, M. (Dir.). (1986b). L'Oeuvre d'Anselme de Cantorbéry 2. Paris: Cerf.

Corbin, M. (Dir.). (1988). L'Oeuvre d'Anselme de Cantorbéry 3. Paris: Cerf.

Études Augustiniennes (Dir.). (1976). Euvres de Saint Augustin 6. Paris: Desclée de Brouwer.

Gilbert, P., Kohlenberger, H., \& Salmann, E. (Eds.). (1999). Cur Deus Homo. Atti del Congresso Anselmiano Internazionale, Roma, 21-23 Maggio 1998. (Studia Anselmiana, 128). Roma: Pontificio Ateneo S. Anselmo.

Heidegger, M. (1976). Only a God can save us now. Der Spiegel 23. In Filosofia III. 1/2 (pp. 109-135). (I. B. Duarte, Port. Trans. and Notes). Lisbon, 1989.

Xavier, M. L. (1991). Necessity and historicity: Reasons of suitability in Saint Anselm’s theology. Itinerarium XXXVIII, $141,353-367$.

\footnotetext{
19 “Qui ergo dicit: 'etiam ista talis esset', aut perfectae superiori uult addere, et erit inmoderatus et iniustus, aut istam uult interimere, et erit malus et inuidus. Qui autem dixerit: 'ista non esset', nihilominus erit malus atque inuidus, cum eam non uult esse quam inferiorem adhuc cogitur, uelut si dicat: 'non esset luna’, cu metiam lucernae claritatem longe inferiorem, in suo tamen genere pulchram et terrenis tenebris decoram atque aptam nocturnis usibus atque in omnibus pro suo modulo utique laudabilem aut fateamur aut stultissime uel contentiose neget. Quo modo ergo recte dicere audebit: 'luna non esset in rebus', qui si diceret: 'lucerna non esset', deridendum se esse sentiret? Quod si non dicit: 'luna non esset', sed qualem solem uidet talem dicit lunam esse debuisse, non intellegit nihil aliud se dicere quam: 'non esset luna, sed essent soles duo'. In quo dupliciter errat, quod rerum perfectioni et addere aliquid cupit, cum desiderat alterum solem, et minuere, cum lunam uult detrahi”. Saint Augustine, De Libero Arbitrio III, 9, 24, in Études Augustiniennes (Dir.), 1976, pp. 428-430.
} 